\title{
Prevalence of Rheumatic Heart Disease and its Risk Factors among Cardiac Patients in Taif City, KSA.
}

\author{
Abdulelah S Algethami ${ }^{(1)}$, Althobaiti, Omar mohammed A ${ }^{(1)}$, Ibrahim H Althomali ${ }^{(1)}$, Gamal M \\ Elnemr $^{(1,2)}$, Mashael A Alzahrani ${ }^{(3)}$, Sultan M Althobaiti ${ }^{(4)}$ \\ 1. Department of Internal Medicine, Faculty of Medicine, Taif University, 2. Department of Medical and Radiological Researches, \\ Nuclear Materials Authority, Egypt, 3. Department of Internal Medicine, King Faisal Hospital , KSA, \\ 4. 1. Department of Pharmacology, Taif University, KSA . \\ *Corresponding Author: Abdulelah S Algethami, E-mail: Dr.abdulelah94@hotmail.com
}

\begin{abstract}
Background: exposure of the body's connective tissue to group A $\beta$-hemolytic streptococci, after an infection, causes an inflammatory response called Rheumatic fever (RF). When the heart's connective tissue is affected, the condition is called Rheumatic heart disease (RDH). Aim of the Work: we aimed at discovering the prevalence of $\mathrm{RDH}$ among cardiac patients and to determine factors that played a role in its development. Also, the study was conducted to find out the causal relationship between early treatment of RF and the occurrence of RHD. Patients and Methods: faisal Hospital's cardiac outpatient clinics, in Taif, KSA, who filled a designed questionnaire after training. To screen the population for the prevalence of $\mathrm{RDH}$ among cardiac patients and to determine factors that played a role in its development. Also, it was conducted to find the causal relationship between early treatment of RF and the occurrence of RHD. The ages were from 18 to 70 years old. Results: the overall prevalence of RHD among cardiac patients was $8 \%$. The difference in prevalence of RHD was statistically significant $(\mathrm{p}=0.021$ ) between patients whose family sizes exceeded 10 individuals (37.5\%) compared to those whose family sizes was 10 individuals or less $(62.5 \%)$. Also, the difference in prevalence of RHD was statistically significant $(\mathrm{p}=0.044)$ between patients who had little (37.5\%) or no knowledge (37.5\%) about symptoms of RHD compared to those who had moderate $(25 \%)$ or good knowledge $(0 \%)$ about symptoms of RHD. The effect of RF management on RHD was studies and it was found that irregular and incomplete antibiotic therapy in case of tonsillitis $(\mathrm{p}=0.006)$ and irregular oral hygiene $(\mathrm{p}=0.027)$ were associated with higher prevalence rates of the disease. Conclusion: The that efficient management of rheumatic fever and acute tonsillitis in terms of adequate antibiotic therapy, good oral hygiene and awareness about the symptoms of RHD are very import aspects to protect against RHD.
\end{abstract}

Keywords: Rheumatic heart disease, Rheumatic fever, Antibiotics, Oral hygiene, Cardiac patients.

\section{INTRODUCTION}

Rheumatic heart disease (RHD) is a condition in which all the three layers of the heart i.e., pericardium, myocardium, and endocardium (including valves), may be permanently damaged ${ }^{(1)}$. RHD is caused by rheumatic fever (RF), an inflammatory complication due to the exposure to group A $\beta$-hemolytic streptococci ${ }^{(1)}$. As the infection becomes recurrent, further damage is inflicted on the heart tissues. The heart valves damage caused by RF forces the heart to work harder to pump blood and, over time, heart-related problems develop such as such as arrhythmias and heart failure ${ }^{(1)}$. RF can occur at any age, but usually occurs in children aging 5 to 14 years old ${ }^{(1)}$. It is more common in developing than developed countries since it is associated with overcrowding, poor sanitation, and other social indicators of poor health ${ }^{(1)}$. RHD related symptoms may vary between one person and another and accordingly, damage to the heart is not usually noticeable. When symptoms appear, they depend on the extent and location of the heart damage. Typically, symptoms of RF appear about three weeks after the onset of an untreated streptococcal throat infection. Apart from the sore throat caused by the streptococcal infection, children have a fever and feel ill. Commonly, the children will have a very painful, swollen, and red joint (usually large joints like knee, ankle, elbow, or shoulder are affected) that goes away after a day or two to be replaced by the same problem in another joint so it is called migratory arthritis. Short-lived skin rashes may also occur, but they are uncommon. If the heart is affected, it is usually not severe enough to cause symptoms, although occasionally the child may complain of dyspnea ${ }^{(1)}$. It is also suggested that poor oral hygiene can lead to dental caries which are correlated with $\mathrm{RF}$ and $\mathrm{RHD}^{(1)}$.We aimed to assess the prevalence of RDH among cardiac patients and to determine socioeconomic demographic factors that played a role in its development.

\section{PATIENTS AND METHODS}

Study design: This was a cross sectional study that was done on 100 cardiac cases who were visiting the cardiac outpatient clinic of King Faisal hospital (KFH), Taif City, KSA to screen the 
population for the prevalence of $\mathrm{RDH}$ among cardiac patients and to determine factors that played a role in its development. Also, it was conducted to find the causal relationship between early treatment of RF and the occurrence of RHD. The ages were from 18 to 70 years old. Data collection: All population participated in the study filled a designed questionnaire after initial training. The questionnaire included questions about; Socio-demographic data (gender, age in years, educational level, residence, economic status, room sharing, living in crowded regions or not, and the family size) and some questions about medical history related to RHD (recurrent sore throat, use of antibiotics in case of having fever symptoms (regular vs. irregular and complete vs. incomplete), using specific type(s) of antibiotic(s), and also it included questions about family history of heart diseases, knowledge level about symptoms of RHD, prevention, and treatment of RF and RHD. Statistical analyses: Data were statistically described in terms of frequencies (number of cases) and valid percentages for categorical variables. Mean, standard deviations, minimum and maximum were used to describe numerical variable. Comparison of categorical variables between the subgroups (crosstabulation) was done using Chi-square/ Fisher exact test. $\mathrm{P}$ values less than 0.05 were considered statistically significant. All statistical calculations were done using computer program IBM SPSS (Statistical Package for the Social Science; IBM Corp, Armonk, NY, USA) release 21 for Microsoft Windows. Ethical considerations: Institutional research ethics board approval was acquired prior to conducting any study procedure.

\section{RESULTS}

\section{Descriptive Analysis}

\section{Patients' characteristics:}

Age: The number of cases whose age was below 50 years was $80 \%$ while those above 50 years constituted 20\%. Gender: Male patients made up 76\% of the population included in the study while $24 \%$ were females. Socio-demographic characteristics of all participants: Out of the 100 participants, $34 \%$ were illiterate, $12 \%$ had completed primary and intermediate education, $22 \%$ had completed secondary education and $32 \%$ had completed university education. As for residence, $86 \%$ lived in the city, $33 \%$ were considered to be living in a crowded region. Around $72 \%$ of the participants shared a room and $12 \%$ were part of a family made up of more than 10 individuals. The monthly income was set to be an indicator for the economic status. Around 3\% of the population was considered of low economic status with income less than 3000 SR/Month, $49 \%$ were considered of good economic status with monthly income between 3000 to 7000 SR while $43 \%$ were considered of very good economic status with monthly income between 7000 to $15000 \mathrm{SR}$. Those with monthly income of more than 15000 SR were considered of excellent income and made up 5\% o of the population. More details are shown in Table (1). Recurrent Sore Throat: The recurrence of sore throat was investigated and $26 \%$ stated that they did suffer from it while $74 \%$ did not have recurrent sore throat.

Table (1): Socio-demographic characteristics of all participants $(\mathrm{N}=100)$

\begin{tabular}{|c|c|c|}
\hline & Frequency & Percentage \\
\hline $\begin{array}{l}\text { Gender } \\
\text { Male } \\
\text { Female } \\
\end{array}$ & $\begin{array}{l}76 \\
24 \\
\end{array}$ & $\begin{array}{l}76 \% \\
24 \% \\
\end{array}$ \\
\hline $\begin{array}{l}\text { Age in years } \\
\quad \leq 50 \\
>50\end{array}$ & $\begin{array}{l}80 \\
20\end{array}$ & $\begin{array}{l}80 \% \\
20 \%\end{array}$ \\
\hline $\begin{array}{l}\text { Education level } \\
\text { Illiterate (not educated) } \\
\text { Primary and intermediate } \\
\text { Secondary } \\
\text { University }\end{array}$ & $\begin{array}{l}34 \\
12 \\
22 \\
32\end{array}$ & $\begin{array}{l}34 \% \\
12 \% \\
22 \% \\
32 \%\end{array}$ \\
\hline $\begin{array}{l}\text { Residence } \\
\text { Village } \\
\text { City }\end{array}$ & $\begin{array}{l}14 \\
86\end{array}$ & $\begin{array}{l}14 \% \\
86 \%\end{array}$ \\
\hline 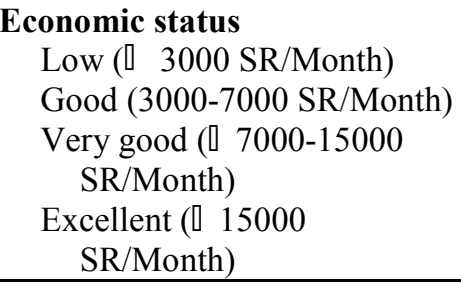 & $\begin{array}{c}3 \\
49 \\
43 \\
5\end{array}$ & $\begin{array}{c}3 \% \\
49 \% \\
43 \% \\
5 \%\end{array}$ \\
\hline $\begin{array}{l}\text { Room sharing } \\
\text { Yes } \\
\text { No } \\
\end{array}$ & $\begin{array}{l}28 \\
72 \\
\end{array}$ & $\begin{array}{l}28 \% \\
72 \% \\
\end{array}$ \\
\hline $\begin{array}{l}\text { Living in crowded regions } \\
\text { Yes } \\
\text { No }\end{array}$ & $\begin{array}{l}33 \\
67\end{array}$ & $\begin{array}{l}33 \% \\
67 \%\end{array}$ \\
\hline $\begin{array}{l}\text { Family size } \\
\quad \leq 10 \\
>10\end{array}$ & $\begin{array}{l}88 \\
12\end{array}$ & $\begin{array}{l}88 \% \\
12 \%\end{array}$ \\
\hline $\begin{array}{l}\text { Recurrent sore throat } \\
\text { Yes } \\
\text { No }\end{array}$ & $\begin{array}{l}26 \\
74\end{array}$ & $\begin{array}{l}26 \% \\
74 \%\end{array}$ \\
\hline
\end{tabular}

Abbreviations: $\mathrm{SR}=$ Saudi Riyals, $\mathrm{N}=$ Number 
Factors associated with RHD prevalence among participants

Patients' characteristics: The prevalence of RHD among the cardiac patients was $8 \%$. There were also several factors tested for association such as gender, education and economic level, residence location and arrangement, family size, recurrent sore throat, knowledge about RF and its prevention, as well as knowledge about the symptoms of RHD and its treatment. The following were found of significance: Family size: Prevalence of RHD among participants with family size of 10 persons or less $(62.5 \%)$ was significantly higher $(p=0.021)$ than that among participants with family size of more than 10 persons $(37.5 \%)$.
Knowledge level about symptoms of RHD: A statistically significant difference $(p=0.044)$ was found between the prevalence of RHD among cardiac patients who have little $(37.5 \%)$ or no knowledge $(37.5 \%)$ about symptoms of RHD compared to those who have moderate $(25 \%)$ or good knowledge $(0 \%)$ about symptoms of RHD. More Details are found in Table 2. 
Abdulelah S Algethami et al.

Table (2): Association between personal factors and RHD prevalence

\begin{tabular}{|c|c|c|c|}
\hline & \multicolumn{2}{|c|}{ RHD } & \multirow[b]{2}{*}{ P-value* } \\
\hline & $\begin{array}{c}\text { Yes(8) } \\
\text { No. }(\%) \\
\end{array}$ & $\begin{array}{l}\text { No }(92) \\
\text { No. }(\%) \\
\end{array}$ & \\
\hline $\begin{array}{l}\text { Gender } \\
\text { Male } \\
\text { Female } \\
\end{array}$ & $\begin{array}{l}7(87.5) \\
1(12.5) \\
\end{array}$ & $\begin{array}{l}69(75) \\
23(25) \\
\end{array}$ & 0.427 \\
\hline $\begin{array}{l}\text { Education level } \\
\text { Illiterate (not educated) } \\
\text { Primary and intermediate } \\
\text { Secondary } \\
\text { University }\end{array}$ & $\begin{array}{l}1(12.5) \\
1(12.5) \\
3(37.5) \\
3(37.5)\end{array}$ & 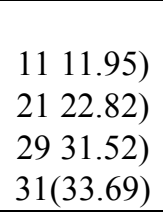 & 0.925 \\
\hline $\begin{array}{l}\text { Residence Area } \\
\text { Village } \\
\text { City } \\
\end{array}$ & $\begin{array}{l}112.5) \\
7(87.5) \\
\end{array}$ & $\begin{array}{l}13(14.13) \\
79(85.86)\end{array}$ & 0.689 \\
\hline 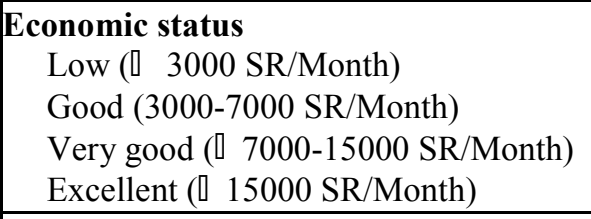 & $\begin{array}{l}0(0) \\
4(50) \\
4(50) \\
0(0)\end{array}$ & $\begin{array}{c}3(3.26) \\
45(48.91) \\
39(42.39) \\
5(5.34) \\
\end{array}$ & 0.850 \\
\hline $\begin{array}{l}\text { Room sharing } \\
\text { Yes } \\
\text { No } \\
\end{array}$ & $\begin{array}{l}2(25) \\
6(75) \\
\end{array}$ & $\begin{array}{l}26(28.27) \\
66(71.73) \\
\end{array}$ & 0.844 \\
\hline $\begin{array}{l}\text { Living in crowded regions } \\
\text { Yes } \\
\text { No } \\
\end{array}$ & $\begin{array}{l}1(12.5) \\
7(87.5) \\
\end{array}$ & $\begin{array}{l}32(34.78) \\
60(65.21) \\
\end{array}$ & 0.189 \\
\hline $\begin{array}{l}\text { Family size } \\
\leq 10 \\
>10 \\
\end{array}$ & $\begin{array}{l}5(62.5) \\
3(37.5)\end{array}$ & $\begin{array}{c}83(90,21) \\
9(9.79)\end{array}$ & $0.021^{*}$ \\
\hline \begin{tabular}{|l} 
Family history of heart diseases \\
Yes \\
No \\
\end{tabular} & $\begin{array}{l}2(25) \\
6(75) \\
\end{array}$ & $\begin{array}{c}6(6.52) \\
86(93.48) \\
\end{array}$ & 0.123 \\
\hline $\begin{array}{l}\text { Recurrent sore throat } \\
\text { Yes } \\
\text { No }\end{array}$ & $\begin{array}{l}3(37.5) \\
5(62.5)\end{array}$ & $\begin{array}{l}23(25) \\
69(75)\end{array}$ & 0.344 \\
\hline
\end{tabular}


Prevalence of Rheumatic Heart Disease and its Risk Factors among Cardiac ....

\begin{tabular}{|c|c|c|c|}
\hline & \multicolumn{2}{|c|}{ RHD } & \multirow[b]{2}{*}{ P-value* } \\
\hline & $\begin{array}{c}\text { Yes(8) } \\
\text { No.(\%) }\end{array}$ & \begin{tabular}{|c|} 
No $(92)$ \\
No. $(\%)$ \\
\end{tabular} & \\
\hline $\begin{array}{l}\text { Knowledge level about RF } \\
\text { Good } \\
\text { Moderate } \\
\text { Little } \\
\text { No } \\
\end{array}$ & $\begin{array}{l}1(12.5) \\
1(12.5) \\
3(37.5) \\
3(37.5) \\
\end{array}$ & $\begin{array}{c}6(6.52) \\
4(4.35) \\
29(31.52) \\
53(57.60)\end{array}$ & 0.579 \\
\hline $\begin{array}{l}\text { Knowledge level about prevention of RF } \\
\text { Good } \\
\text { Moderate } \\
\text { Little } \\
\text { No } \\
\end{array}$ & $\begin{array}{l}0(0.0) \\
2(25) \\
3(37.5) \\
3(37.5) \\
\end{array}$ & $\begin{array}{c}6(6.52) \\
5(5.43) \\
29(31.52) \\
52(56.52)\end{array}$ & 0.164 \\
\hline $\begin{array}{l}\text { Knowledge level about symptoms of RHD } \\
\text { Good } \\
\text { Moderate } \\
\text { Little } \\
\text { No }\end{array}$ & $\begin{array}{l}0(0.0) \\
2(25) \\
3(37.5) \\
3(37.5)\end{array}$ & $\begin{array}{c}7(7.60) \\
3(3.26) \\
52(56.52) \\
3032.60)\end{array}$ & $0.044 *$ \\
\hline $\begin{array}{l}\text { Knowledge level about treatment of RHD } \\
\text { Good } \\
\text { Moderate } \\
\text { Little } \\
\text { No }\end{array}$ & $\begin{array}{c}0(0.0) \\
1(12.5) \\
3(37.5) \\
4(50)\end{array}$ & $\begin{array}{l}3(3.26) \\
2(2.17) \\
5964.13) \\
28(30.43)\end{array}$ & 0.204 \\
\hline
\end{tabular}

Chi-square/Fisher exact test $(\mathrm{P}<0.05$ is considered significant $)$ * 


\section{Relationship between treatment of RF and occurrence of RHD}

Results showed that using antibiotics in the management of fever $(p=0.595)$ and types of antibiotics $(p=0.441)$ used had no significant effect on RHD prevalence while using antibiotics in the management of tonsillitis $(p=0.006)$ and good oral hygiene $(\mathrm{p}=0.027)$ were found to have a significant protective effect against RHD as shown in table 3 .

Table 3: Relationship between treatment of RF and occurrence of RHD

\begin{tabular}{|c|c|c|c|}
\hline & \multicolumn{2}{|c|}{ RHD } & \multirow{2}{*}{$\begin{array}{c}\text { P- } \\
\text { value* }\end{array}$} \\
\hline & \begin{tabular}{|c|} 
Yes $(8)$ \\
No. $(\%)$ \\
\end{tabular} & \begin{tabular}{|l|} 
No (92) \\
No. $(\%)$
\end{tabular} & \\
\hline $\begin{array}{l}\text { Action in case of having symptoms of } \\
\text { tonsillitis } \\
\text {-Receive prescribed antibiotics } \\
\text { completely and regularly } \\
\text {-Don't receive prescribed antibiotics } \\
\text { completely or regularly } \\
\text {-Receive over the counter antibiotics } \\
\text {-Don't receive antibiotics at all }\end{array}$ & $\begin{array}{l}3(37.5) \\
3(37.5) \\
1(12.5) \\
1(12.5)\end{array}$ & $\left|\begin{array}{l}55(59.78) \\
4(4.35) \\
11(11.95) \\
22(23.91)\end{array}\right|$ & $0.006^{*}$ \\
\hline $\begin{array}{l}\text { Using antibiotics in case of having } \\
\text { fever symptoms } \\
\text { Yes } \\
\text { Sometimes } \\
\text { No }\end{array}$ & $\begin{array}{c}2(25) \\
5(62.5) \\
1(12.5)\end{array}$ & $\mid \begin{array}{c}19(20.65) \\
46(50) \\
27(29.35)\end{array}$ & 0.595 \\
\hline $\begin{array}{l}\text { Using specific type of antibiotic } \\
\text { Yes } \\
\text { No } \\
\end{array}$ & $\begin{array}{l}2(25) \\
6(75) \\
\end{array}$ & $\begin{array}{l}16(17.39) \\
76(82.61) \\
\end{array}$ & 0.441 \\
\hline $\begin{array}{l}\text { Care about mouth cleaning } \\
\text { Yes } \\
\text { Sometimes } \\
\text { No }\end{array}$ & $\begin{array}{r}1(12.5) \\
4(50) \\
3(37.5)\end{array}$ & $\begin{array}{l}34(36.95) \\
41(44.56) \\
17(18.48)\end{array} \mid$ & $0.027^{*}$ \\
\hline
\end{tabular}

\section{DISCUSSION}

Rheumatic heart disease is a common condition among low and middle income regions of the world with 33 million people living with rheumatic heart disease worldwide ${ }^{(1)}$.To the best of our knowledge, the current study is the first study done to estimate the prevalence of RHD in cardiac patient population in Taif City. One hundred patients were enrolled and their data were collected through a designed questionnaire covering sociodemographic data, medical history related to RHD in addition to knowledge level about symptoms of RHD and management of RF and RHD. In our study population, results showed that $8 \%$ of the cardiac patients were suffering from RHD with no significant difference between males and females $(p=0.427)$. On the other hand, recent findings stated that females are more likely to have RHD. ${ }^{(1)}$ This may be due to the unequal gender distribution in our study as females constituted less than one quarter of the population. Our study showed a significantly higher prevalence of RHD in households with less than 10 individuals $(\mathrm{p}=0.021)$. This is contradictory to recent data that showed an association between RHD and crowded households that can increase the risk of infection ${ }^{(3,9)}$. This may be due to the small number of subjects with RHD in our study (8 subjects). Results of our study also revealed that high level of awareness about RHD symptoms can significantly reduce the risk of developing RHD $(p=0.044)$. This is because higher awareness level will allow better management of RF and will increase patients' compliance to the RHD treatment plans. ${ }^{(12)}$ According to the literatures, ensuring higher living standards is believed to be a significant player in the prevention of RF and RHD. ${ }^{(1,2,3)}$ In our study, living economic status, education level, residence area and crowdedness of the living region were used to measure the quality of life, but these parameters did not prove to be considerable factors as none showed significant impact on the risk of developing RHD $(p=0.85, \quad p=0.925, \quad p=0.689$, $\mathrm{p}=0.189$ respectively). In our study population, the regular and complete use of antibiotics as a treatment for acute tonsillitis was found to be significantly associated with a lower risk of RHD development $(\mathrm{p}=0.006)$. This is consistent with the literatures which stated that regular and complete use of prescribed antibiotics is important to avoid resistance of bacteria such as streptococci and enhance the eradication process that is a crucial step in the early and proper treatment of $\mathrm{RF}^{(1,2)}$. It is usually reported that RF and RHD are associated with recurrent upper respiratory tract infections ${ }^{(1)}$. However, our data showed that there was no significant correlation between recurrent sore throat infection and RHD ( $p=0.344)$. Our study showed that irregular oral hygiene was significantly associated with higher prevalence rates of RHD $(\mathrm{p}=0.027)$. The findings of Thornley et al. support our evidence that oral hygiene is essential to decrease the risk of RF occurrence ${ }^{(7)}$.

\section{CONCLUSION}

Based on the discussed results, it can be concluded that efficient management of rheumatic fever and acute tonsillitis in terms of adequate antibiotic therapy, good oral hygiene and 
awareness about the symptoms of RHD are very import aspects to protect against RHD. It will be of a great benefit to conduct tailored campaigns aiming at raising the awareness level of healthcare providers and the population about RHD disease and how to protect one's self against it.

\section{CONFLICTS OF INTEREST}

There are no conflicts of interest.

\section{REFERENCES}

1. Carapetis JR, Currie BJ, Mathews JD (2000): Cumulative incidence of rheumatic fever in an endemic region: a guide to the susceptibility of the population. Epidemiology \& Infection, 124(2):239-44.

2. Watkins DA, Johnson CO, Colquhoun SM, Karthikeyan G, Beaton A, Bukhman G, Forouzanfar MH, Longenecker CT, Mayosi BM, Mensah GA, Nascimento BR (2017): Global, regional, and national burden of rheumatic heart disease, 19902015. New England Journal of Medicine, 377(8):713-22.

3. Watkins DA, Johnson CO, Colquhoun SM, Karthikeyan G, Beaton A, Bukhman G, Forouzanfar MH, Longenecker CT, Mayosi BM, Mensah GA, Nascimento BR( 2017): Global, regional, and national burden of rheumatic heart disease, 19902015. New England Journal of Medicine, 377(8):713-22.

4. Marijon E, Mirabel M, Celermajer DS, Jouven $X$ (2012): Rheumatic heart disease. The Lancet,379(9819):953-64.

5. Thornley S, Marshall RJ, Bach K, Koopu P, Reynolds G, Sundborn G, Ei WL ( 2017) : Sugar, dental caries and the incidence of acute rheumatic fever: a cohort study of Māori and Pacific children. J Epidemiol Community Health, 71(4):364-70.

6. Yacoub M, Mayosi B, ElGuindy A, Carpentier A, Yusuf S (2017): Eliminating acute rheumatic fever and rheumatic heart disease. The Lancet, 390(10091):212-3.
7. Karthikeyan G, Guilherme L (2017): Acute rheumatic fever. The Lancet, 29.(2): 15.

8. Al-Jazairi A, Al-Jaser R, Al-Halees $\mathbf{Z}$, Shahid M, Al-Jufan M, Al-Mayouf S, Al-Rajhi A, Al-Hajjar S (2017) : Guidelines for the secondary prevention of rheumatic heart disease: Endorsed by Saudi Pediatric Infectious Diseases Society (SPIDS). International Journal of Pediatrics and Adolescent Medicine, 4(1):47-50.

9. Steer AC, Kado J, Colquhoun S, Noonan S, Babitu T (2006): Awareness of rheumatic heart disease. The Lancet, 367(9528):2118.

10. Taranta A, Markowitz $M$ (2012) : Rheumatic fever. Springer Science \& Business Media . www.springer.com

11. Parnaby MG, Carapetis JR (2010) : Rheumatic fever in indigenous Australian children. Journal of paediatrics and child health, 46(9):527-33.

12. Carapetis JR, McDonald M, Wilson NJ (2005) : Acute rheumatic fever. The Lancet, 366(9480):155-68.

13. Robertson KA, Volmink JA, Mayosi BM (2005) : Antibiotics for the primary prevention of acute rheumatic fever: a meta-analysis. BMC Cardiovascular Disorders, 5(1):11.

14. Corsenac $P$, Heenan RC, Roth A, Rouchon B, Guillot N, Hoy D (2016) : An epidemiological study to assess the true incidence and prevalence of rheumatic heart disease and acute rheumatic fever in new Caledonian school children. Journal of paediatrics and child health, 52(7):739-44.

15. Corsenac $P$, Heenan RC, Roth A, Rouchon B, Guillot N, Hoy D (2016) : An epidemiological study to assess the true incidence and prevalence of rheumatic heart disease and acute rheumatic fever in new Caledonian school children. Journal of paediatrics and child health, 52(7):739-44. 